\title{
Miranda
}

Revue pluridisciplinaire du monde anglophone /

Multidisciplinary peer-reviewed journal on the English-

speaking world

$14 \mid 2017$

Early American Surrealisms, 1920-1940 / Parable Art

\section{Conference Report: Women Who Kill in English- Speaking Cinema and TV Series of the Postfeminist} Era

13-14 October 2016. University of Toulouse Jean Jaurès.Symposium organized by Zachary Baqué, Cristelle Maury and David Roche

Sarah Campion and Lénora Lardy

\section{(2) OpenEdition}

\section{Journals}

Electronic version

URL: http://journals.openedition.org/miranda/10264

DOI: 10.4000/miranda.10264

ISSN: 2108-6559

Publisher

Université Toulouse - Jean Jaurès

Electronic reference

Sarah Campion and Lénora Lardy, "Conference Report: Women Who Kill in English-Speaking Cinema and TV Series of the Postfeminist Era", Miranda [Online], 14 | 2017, Online since 19 April 2017, connection on 16 February 2021. URL: http://journals.openedition.org/miranda/10264 ; DOI: https:// doi.org/10.4000/miranda.10264

This text was automatically generated on 16 February 2021.

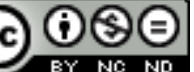

Miranda is licensed under a Creative Commons Attribution-NonCommercial-NoDerivatives 4.0 International License. 


\title{
Conference Report: Women Who Kill in English-Speaking Cinema and TV Series of the Postfeminist Era
}

\author{
13-14 October 2016. University of Toulouse Jean Jaurès.Symposium
} organized by Zachary Baqué, Cristelle Maury and David Roche

\author{
Sarah Campion and Lénora Lardy
}

The topic of this conference does not, on the face of it, present anything new. Indeed, the last forty years have been overflowed with research on the figure of the murderous woman and the various types of characters associated with it (the jealous girlfriend, the monstrous woman). This conference, however, focused on the Postfeminist era and considered women who kill in the light of the recent shift in the queer position that has, for the last twenty-five or so years, encouraged a more flexible understanding of questions of gender and sexuality. Over the course of this two-day symposium, eight speakers divided into three panels of two or three speakers explored this shift, evidencing the gendered distinctions between male and female violence: the second has often been associated with a motive to be violent and to kill. A woman who kills does so for a reason: she wants revenge, has been a victim, wants to protect her children, and so on. Female violence is rarely presented as purely sadistic and is often grounded in traditional views of victimhood and motherhood associated with femaleness. In his opening speech, David Roche announced the new questions raised by this follow-up of the Femmes Meurtrières symposium on 19th and 20th century literature, organized by Aurélie Guillain, Emeline Jouve, Laurence Talairach-Vielmas and Héliane Ventura, held in Winter 2015. Redirecting the focus from a film studies perspective, Roche evoked the 1980s and 1990s groundbreaking studies of scholars since Mulvey, such as Mary Ann Doane, Annette Kuhn, Janey Place, Carol Clover and Barbara Creed regarding the various representations of women in relation to film genre. Walking in the footsteps of feminist film theory, Roche reckoned that this symposium would expose the dialogue between audience and film - through the analysis of narrative structures and aesthetics - fueled by contemporary debates on feminism, including post-feminism. This exposure suggested many valuable 
perspectives, he explained, such as the link between filmmakers and feminist film theory, the oddity and displacement of female violence or the question of the blurring of genders.

In the first panel dedicated to "Action Women," Elizabeth Mullen, from the University of Bretagne Occidentale in Brest, presented a comparison between female protagonists from two very different films. The box-office-success comedy Spy (Paul Feig, 2015), a parody of James Bond films, and the Academy Award Nominated Sci-Fi action blockbuster Mad Max: Fury Road (George Miller, 2015). Mullen focused more precisely on the reactions of spectators online, which turned out to be very different for these two films. Both films have in common that they present a female protagonist taking up the main role previously occupied by a man (Mad Max or Bond). On the one hand, the release of the trailer of Mad Max before the film's release triggered extreme reactions from the "manosphere," that is websites made by and for men that are openly misogynistic. They expressed a clear discontent at the female heroine in what was expected to be a classic "male action film." For them, the very existence of a woman who kills in such a blockbuster disrupts the order of the entire film industry and testifies to an overt intent to assimilate feminist views. On the contrary, the release of spy did not trigger any reaction from the male sphere online and garnered some approval from feminists. The question remains: why was there no backlash when a woman took James Bond's role?

3 Isabelle Schmitt-Pitiot, Associate Professor of English at the University of Bourgogne, then studied the ambiguity of the series Hit \& Miss (Sky Atlantic, 2012), in which Chloë Sevigny embodies the male-to-female transgender contract-killer Myra. This two-sided character articulates the issues of gender, sexuality and violence, offering contradictory views on them. Here, the character's male and female body (the viewer is constantly reminded of the fact that she has a penis) reflects this combination. The series both depicts and questions a binary view of the world by forcing the transgender body into a realistic setting, thus focusing more on the unusual act of killing for no apparent reason (or for money) than on the queer body that does it. Schmitt-Pitiot finally suggested a solution to the contradictions raised by this character by underlining the creation of a hybrid discourse through doubles and mirrors, but also in the intertextuality developed by the series, a parallel discourse that encourages us to accept the blurring of boundaries.

Shannon Wells-Lassagne, Professor of film studies at the University of Bourgogne (Dijon) presented a comparison between Arya Stark and Brienne of Tarth, two characters from the TV show Game of Thrones (HBO, 2011-). She explored how the two characters are clearly identified as both women who kill and sympathetic characters by studying their first appearance in the show. Arya and Brienne show physical similarities in terms of costumes and behavior. The two characters are typical of a show that establishes unreliable gender norms. For instance, Brienne's first appearance takes place during a fight for her King. Her face is hidden, and she wins over a male knight. When she reveals her face and thus her sex, she asserts her superiority over a male counterpart before a King who is having sexual relationships with his wife 's brother. Arya, on the other hand, becomes a trained assassin and displays androgynous physical traits. Through this study, Wells-Lassagne accounted for a new type of woman who kills in a genre, fantasy, where female warriors are traditionally sexually fetishized. 
5 The second panel dealt with a staple figure of film noir: the femme fatale. Cristelle Maury, Associate Professor at the University of Toulouse 2 Jean Jaurès, who recently wrote an article on Todd Haynes's readaptation of Mildred Pierce (HBO, 2011), examined how film noir interacts with feminist film theory. Her talk drew attention to the evolution of the femme fatale from noir to neo-noir and to the post-feminist era, through the analysis of Gone Girl (David Fincher, 2014). She emphasized the contradictory characterization of Amy, navigating between the sexual and mysterious femme fatale and the still child-like nurturing woman. This very convincing analysis was grounded in a comparison of Fincher's film's aesthetics with recent neo-noir, including Body Heat (Lawrence Kasdan, 1981), Fatal Attraction (Adrian Lyne, 1987), Basic Instinct (Paul Verhoeven, 1992) and Taking Lives (D.J. Caruso, 2004). Maury also evoked 1940s and 1950s film noir, such as Possessed (Curtis Bernhardt, 1947), Sunset Boulevard (Billy Wilder, 1950) and Angel Face (Otto Preminger, 1953), with a special focus on their female characters embodied respectively by Joan Crawford, Gloria Swanson and Jean Simmons. Her comparative analysis emphasized the deconstruction and transformation of the femme fatale due to aesthetic de-eroticization, making Amy either a nurturing woman gone wild or a femme fatale gone nurturing. Moreover, as a victim of the media, Amy is only what she represents, so that her only identity is nothing more than the one she performs. Maury's analysis of this complex character in a movie blending film noir and neo-noir characteristics highlighted paradoxes inherent to postfeminism.

6 Adrienne Boutang, Associate Professor of film studies at the University of Franche Comté, Besançon, focused on the relationship between young teenage girls and female villains in the dystopian young adult fictions The Hunger Games (Gary Ross, 2012), The Hunger Games: Catching Fire (Francis Lawrence, 2013), The Hunger Games: Mockingjay (Francis Lawrence, 2014 - 2015), Divergent (Neil Burger, 2014), Insurgent (Robert Schwentke, 2015) and The 5th Wave (J. Blakeson, 2016). Some of these films have been praised as feminist by the critics. Boutang's analysis, which included both the actual women in these fictions-who have not been the focus of critics writing on feminismand the teenage girls, demonstrated how this representation reflects current feminist debates. Boutang went from analyzing the warrior girls' androgynous appearances and their ability to kill only when absolutely needed, highlighting their defiance of gender roles as they switch from feminine to tomboyish whenever they please, to commenting on the duplicity of the more mature women's feminine looks but cyborg-like antifeminine behavior induced by patriarchy. Boutang concluded that teenage girls seem to be more accepted and valued than empowered "bitchy" women, who are deprived of any potential contemporary feminist de-evilizing backstories. Boutang ultimately argued that, regarding the difference in portrayal of women and girls, these films reflect the ambiguity of post-feminism and girl culture: by killing empowered women, the young girls are metaphorically toppling their feminist mothers.

7 The last panel dealt with "Monstrous Women" in gothic and horror movies. Diane Deplante, a PhD Candidate at the University of Perpignan Via Domitia, demonstrated that the horror movies Teeth (Michel Linchtenstein, 2007) and Jennifer's Body (Karyn Kusama, 2009) subtextually address the issue of rape culture. In doing so, both movies invert the usual status of gender in horror movies. Indeed, the fact that women are imbued with violence is already a displacement, since gruesome murders are generally depicted as male deeds. While women are usually victims, in Linchtensein's and Kusama's movies, they become murderous monsters who transgress the gendered 
dichotomy of violence. Men, though they are still villains, become victims who need "pink ladies' pepper spray." By showing several gruesome scenes from both movies, Deplante pointed out the key element of this gender inversion: the figure of the vagina dentata, i.e., toothed female genitalia. The myth is used to invert and criticize the traditional narratives of horror movies, explicitly targeted through visual references such as movie posters, in both Teeth and Jennifer's Body, where women are victims of men. Thanks to their lethal genitalia, the female characters evolve from the status of victim to avenging perpetrator as they acquire the ability to punish monstrous sexuality, usually by castrating the male characters who intend to assault them. Deplante went on to contend that, rather than just display a positive image of women in mainstream representations, mainstream cinema is a "fertile ground" to carry on the societal discussion of women's control over their sexuality, leading to the rejection of feminine victimhood.

8 Finally, Carolina Abello Onofre, who has a Bachelor of Arts in Modern Languages, and Christophe Chambost, Associate Professor at Université Bordeaux Montaigne, discussed the presence of she-devils and furies in the movies Byzantium (Neil Jordan, 2012), The Woman in Black (James Watkins, 2012) and Crimson Peak (Guillermo del Toro, 2015). After showing key passages in the representation of she-devils from all three movies, Onofre and Chambost commented on the rebellious female figures and their inclusion in a Victorian setting, which induces a questioning of deeply seated patriarchal norms in each movie. They analyzed the inclusion of different forms of art in the narration of Byzanthium and Crimson Peak as symbolizing an opposition to male superiority in the first and the decline of a criticized aristocracy in the second. They went on to question the lesser political content of Watkins' readaptation The Woman in Black, compared to the original 1983 novel and the 1989 TV film, suggesting that it is typical of the search for the sensational in the late twentieth and early twenty-first centuries horror movies. Referring to the vampire novels and ghost stories of Victorian times, the two speakers showed that the female murderers and the feminists opposing patriarchy in these films were empowered female characters who do not abandon their goals, even though they are in conflict with the patriarchal society they live in.

9 Overall, this symposium exposed the complexity and panorama of characterizations of the female killer. A complexity often paired with a resistance to a patriarchal system from a post-feminist angle opposed to the feminist perspective preceding it. Indeed, the different talks foregrounded the response of post-feminist representations of women to gender differentiation and norms, which the feminist perspective often indulges in. This bold response deconstructs and points out what is left of patriarchy in our contemporary society, but mostly within the cinema industry itself, laying in the displacement of traditional characterizations. 
INDEX

Keywords: English-speaking cinema, feminism, postfeminism, gender, action film, TV Series, film noir, young adult dystopia, horror film, gothic, film studies

Subjects: Film

\section{AUTHORS}

\section{SARAH CAMPION}

Master's Student

Université Toulouse Jean Jaurès

campionsarah@ymail.com

\section{LÉNORA LARDY}

Professeure Agrégée (English Teacher)

lenora.lardy@hotmail.fr 